\title{
Association between uric acid level and incidence of macroalbuminuria in people with type 2 diabetes mellitus: A 4.5-year cohort study
}

\section{Yun-Ju Lai}

Taichung Veterans General Hospital Puli Branch

\section{Yu-Yen Chen}

Taichung Veterans General Hospital

Li-Jung Chen

National Taiwan Sport University

\section{Po-Wen Ku}

National Changhua University of Education

Kuo-Chuan Hung

Chi Mei Medical Center

\section{Yung-Feng Yen}

Taipei City Hospital

Yu-Kai Lin ( $\nabla$ yklin@utaipei.edu.tw )

University of Taipei https://orcid.org/0000-0002-2668-9833

\section{Research article}

Keywords: uric acid, type 2 diabetes mellitus, risk factors, macroalbuminuria, cohort study

Posted Date: December 10th, 2019

DOI: https://doi.org/10.21203/rs.2.18350/v1

License: (c) (i) This work is licensed under a Creative Commons Attribution 4.0 International License. Read Full License 


\section{Abstract}

Background: Using animal models and molecular biology researches, hyperuricemia has been shown to instruct renal arteriolopathy, arterial hypertension, and microvascular injury involving the reninangiotensin system and resulting in renal function impairment. Nevertheless, the association between uric acid levels and the development of macroalbuminuria has been under-investigated in people with type 2 diabetes mellitus.

Methods: Patients with type 2 diabetes and regular outpatient visits were recruited from a community hospital in Taiwan since January 2014. Demographics, lifestyle features, and medical history were gathered by well-trained interviewers. All participants underwent comprehensive physical examinations, including a biochemical assay of venous blood specimens and urine samples after an 8-hour overnight fast. Participants were followed until June 2018. The primary outcome was the macroalbuminuria incidence. Univariable and multivariable Cox regression analysis were employed to explore the relation between uric acid and incident macroalbuminuria. Uric acid cutoffs for incident macroalbuminuria were determined with the receiver operator characteristic curve.

Results: We included 247 qualified subjects (mean age: 64.78 years old [standard deviation $=11.29$ years]; 138 [55.87\%] men). During a 4.5-year follow-up duration, 20 subjects with incident macroalbuminuria were recognized. Serum uric acid was significantly associated with an increased risk of incident macroalbuminuria (adjusted hazard ratio=2.39; $95 \%$ confidence interval: $1.53-3.75 ; p<0.001$ ) with potential confounders adjustment. The uric acid cutoff point was $6.9 \mathrm{mg} / \mathrm{dL}$ (area under the curve 0.708 , sensitivity $60.0 \%$, specificity $84.58 \%$ ) for incident macroalbuminuria.

Conclusions: Serum uric acid was associated with incident macroalbuminuria among people with type 2 diabetes.

\section{Background}

Diabetic nephropathy is a cardinal source of chronic renal failure, which is a major health concern that results in an increased risk of cardiovascular disease and death worldwide [1,2]. The indicator to identify subjects at risk for glomerular filtration rate declining is macroalbuminuria [3]. Previous studies have confirmed that risk factors associated with diabetic nephropathy included genetic factors, hyperglycemia, hyperlipidemia, hypertension, and smoking [4].

Recently, several researches suggested that increased uric acid levels may damage renal function. Elevation of uric acid levels not only stimulates the renin-angiotensin system but also reduces endothelial nitric oxide synthetase [5], leading to damage of endothelial and vascular smooth muscle cells, finally cause microvascular disease [6-8]. Animal researches have revealed that elevated serum uric acid levels may induce endothelial dysfunction and promote the kidney function worsening $[9,10]$. 
In humans, recent epidemiologic research has also discovered that elevated uric acid levels were related to chronic kidney disease in community residents and those with type 2 diabetes [11-14]. In east Asia, two community-based cohort studies with healthy middle-aged or older participants reported that, after a follow-up duration of 4 years, hyperuricemia at more than $7.0 \mathrm{mg} / \mathrm{dL}$ of serum uric acid put people at a significantly higher risk of an insufficient glomerular filtration rate or microalbuminuria with confounding adjustment $[11,12]$. Similar outcomes were found in individuals with type 2 diabetes regarding the relation between serum uric acid and risk of albuminuria or decreased glomerular filtration rate [13-16]. Overall estimations of the relationship between serum uric acid concentration and poor kidney function were consistently moderate to high [13-16]. However, these researches of the relation between uric acid and diabetic nephropathy had diverse outcome definitions [13-16], and potential confounders were not fully considered [14-16]. In addition, the cutoff level of uric acid related with an increased risk of macroalbuminuria has not yet been well investigated. Consequently, we intended to investigate the association between uric acid level and the incidence of macroalbuminuria in people with type 2 diabetes and to estimate the uric acid cutoff levels.

\section{Methods}

\section{Setting and participants}

This was a cohort study accomplished at the Puli Branch of Taichung Veterans General Hospital, which is a local community hospital in the Puli Township of Nantou County in Taiwan. Since January 2014, people with type 2 diabetes having regular outpatient visits at the Division of Endocrinology and Metabolism were included in the study. All patients signed written informed consent forms. Patients with disabilities, those who were bedridden, and those who were unable to answer the questionnaire were excluded from the study. Those with macroalbuminuria, which was defined as a urine albumin-creatinine ratio of more than $300 \mathrm{mg} / \mathrm{g}$ on a spot sample, were excluded. Participants were followed until June 2018.

\section{General assessment}

Demographic and anthropometric measurements were obtained during the outpatient visits. Blood pressure, body height, and weight were measured using standardized processes and recorded by interviewers. The definitions of overweight (body mass index $\geqq 24 \mathrm{~kg} / \mathrm{m}^{2}$ ) and obesity (body mass index $\geqq 27 \mathrm{~kg} / \mathrm{m}^{2}$ ) were recommended by the Taiwan Health Promotion Administration, Ministry of Health and Welfare [17]. Information regarding baseline characteristics, such as education levels, marital status, and smoking, betel nut chewing, and drinking habits were gathered by standardized face-to-face interviews. All the study subjects underwent a comprehensive health examination, including blood pressure measurement and the collection of serum and urine specimens for a biochemical assay after fasting overnight for 8 hours. Measurements of fasting glucose, hemoglobin A1c (HbA1c), serum uric acid, creatinine, lipid profiles, and albumin-creatinine ratio in spot urine samples were obtained. Devices used 
for measuring the values of plasma glucose, serum uric acid, creatinine, and all lipid profiles were based on an enzymatic analysis (SIEMENS Dimension ${ }^{\circledR}$ EXL 200, Germany).

\section{Outcome covariates}

Microalbuminuria is defined as a urine albumin-creatinine ratio of 30 to $300 \mathrm{mg} / \mathrm{g}$ in a spot sample. The outcome of interest in this analysis was macroalbuminuria, which is identified as a urine albumincreatinine ratio of more than $300 \mathrm{mg} / \mathrm{g}$ on a spot sample [18].

\section{Statistical analysis}

First, a univariate Cox regression analysis was used to access the baseline demographics of the study participants. A multivariate Cox regression analysis was used to explore the association of serum uric acid levels with incident macroalbuminuria. Adjusted hazard ratios (AHR) with 95\% confidence intervals (Cl) were stated to demonstrate the intensity and direction of these associations. The sensitivity, specificity, positive and negative predictive values, and area under the receiver operator characteristic (ROC) curve (AUC) were estimated. Uric acid cutoffs for the incidence of macroalbuminuria were calculated with the ROC curve. Statistical analysis was performed by the SAS software version 9.4. The statistical significance level (alpha level) was considered as 0.05 .

\section{Results}

A total of 279 people with diabetes were interviewed since January 2014. Individuals with macroalbuminuria ( $n=32)$ were excluded. Finally, the data of 247 people with diabetes were analyzed in this research. The mean (standard deviation) age of the study subjects was 64.74 (11.29) years, and 138 (55.87\%) participants were men. Participants were followed until June 2018. During the $3.32 \pm 1.23$ years of follow-up, 20 individuals had new-onset macroalbuminuria.

Table 1 reveals the results of the univariate Cox regression model. Those with higher uric acid levels had an increased risk of incident macroalbuminuria (HR, 1.73; 95\% $\mathrm{Cl} 1.29-2.32, \mathrm{p}<0.001)$. Other variates associated with the development of macroalbuminuria were older age, male sex, never married, moderate education, betel nut chewing, hypertension, hyperglycemia, and hyperlipidemia. 
Table 1

Characteristics and results of univariable Cox regression analysis of the study population ( $n=247 ; 20$ macroalbuminuria cases)

\begin{tabular}{|c|c|c|c|c|c|}
\hline Demographics & $\begin{array}{l}\text { Mean } \pm \text { SD / } \\
\text { Numbers } \\
\text { (\% in column) } \\
n=247\end{array}$ & $\begin{array}{l}\text { Number of } \\
\text { Macroalbuminuria } \\
\text { (\% in row) } \\
n=20\end{array}$ & $\begin{array}{l}\text { Hazard } \\
\text { Ratio }\end{array}$ & $(95 \% \mathrm{Cl})$ & $\begin{array}{l}\mathrm{p} \text { - } \\
\text { value }\end{array}$ \\
\hline Uric acid (mg/dL) & $5.54 \pm 1.45$ & $6.56 \pm 1.54$ & 1.73 & $\begin{array}{l}(1.29- \\
2.32)\end{array}$ & $\begin{array}{l}<.001 \\
0.001\end{array}$ \\
\hline Age in years, mean (SD) & $64.78 \pm 11.29$ & $65.40 \pm 13.18$ & 1.01 & $\begin{array}{l}(0.97- \\
1.05)\end{array}$ & 0.56 \\
\hline $\begin{array}{l}\text { Gender } \\
\text { Female } \\
\text { Male }\end{array}$ & $\begin{array}{l}109(44.13 \%) \\
138(55.87 \%)\end{array}$ & $\begin{array}{l}7(6.42 \%) \\
13(9.42 \%)\end{array}$ & $\begin{array}{l}\text { Ref } \\
1.59\end{array}$ & $\begin{array}{l}(0.63- \\
4.01)\end{array}$ & 0.32 \\
\hline $\begin{array}{l}\text { Marriage status } \\
\text { Married/cohabiting } \\
\text { Never married } \\
\text { Widowed/divorced/separated }\end{array}$ & $\begin{array}{l}194(79.18 \%) \\
13(5.31 \%) \\
38(15.51 \%)\end{array}$ & $\begin{array}{l}16(8.25 \%) \\
3(23.08 \%) \\
1(2.63 \%)\end{array}$ & $\begin{array}{l}\text { Ref } \\
3.81 \\
0.35\end{array}$ & $\begin{array}{l}(1.09- \\
13.41) \\
(0.05- \\
2.63)\end{array}$ & $\begin{array}{l}0.04 \\
0.31\end{array}$ \\
\hline $\begin{array}{l}\text { Education } \\
\text { Low (elementary or below) } \\
\text { Moderate (junior/senior high) } \\
\text { High (college or above) }\end{array}$ & $\begin{array}{l}81(37.67 \%) \\
98(45.58 \%) \\
36(16.74 \%)\end{array}$ & $\begin{array}{l}6(7.41 \%) \\
8(8.16 \%) \\
1(2.78 \%)\end{array}$ & $\begin{array}{l}\text { Ref } \\
1.28 \\
0.39\end{array}$ & $\begin{array}{l}(0.44- \\
3.73) \\
(0.05- \\
3.28)\end{array}$ & $\begin{array}{l}0.65 \\
0.39\end{array}$ \\
\hline $\begin{array}{l}\text { Body mass index }\left(\mathrm{kg} / \mathrm{m}^{2}\right) \\
<24 \\
24 \leq \mathrm{BMI}<27 \\
\geq 27\end{array}$ & $\begin{array}{l}77(31.56 \%) \\
88(36.07 \%) \\
79(32.38 \%)\end{array}$ & $\begin{array}{l}9(11.69 \%) \\
5(5.68 \%) \\
5(6.33 \%)\end{array}$ & $\begin{array}{l}\text { Ref } \\
0.45 \\
0.44\end{array}$ & $\begin{array}{l}(0.15- \\
1.36) \\
(0.15- \\
1.33)\end{array}$ & $\begin{array}{l}0.16 \\
0.15\end{array}$ \\
\hline $\begin{array}{l}\text { Smoking status } \\
\text { Never } \\
\text { Current } \\
\text { Former }\end{array}$ & $\begin{array}{l}172(69.64 \%) \\
58(23.48 \%) \\
17(6.88 \%)\end{array}$ & $\begin{array}{l}14(8.14 \%) \\
5(8.62 \%) \\
1(5.88 \%)\end{array}$ & $\begin{array}{l}\text { Ref } \\
0.93 \\
0.90\end{array}$ & $\begin{array}{l}(0.33- \\
2.58) \\
(0.12- \\
6.87)\end{array}$ & $\begin{array}{l}0.89 \\
0.92\end{array}$ \\
\hline $\begin{array}{l}\text { Drinking } \\
\text { Never } \\
\text { Current } \\
\text { Former }\end{array}$ & $\begin{array}{l}190(76.92 \%) \\
45(18.22 \%) \\
12(4.86 \%)\end{array}$ & $\begin{array}{l}16(8.42 \%) \\
3(6.67 \%) \\
1(8.33 \%)\end{array}$ & $\begin{array}{l}\text { Ref } \\
0.86 \\
0.90\end{array}$ & $\begin{array}{l}(0.25- \\
2.94) \\
(0.12- \\
6.85)\end{array}$ & $\begin{array}{l}0.80 \\
0.92\end{array}$ \\
\hline $\begin{array}{l}\text { Betel nut } \\
\text { Never } \\
\text { Current } \\
\text { Former }\end{array}$ & $\begin{array}{l}219(88.66 \%) \\
16(6.48 \%) \\
12(4.86 \%)\end{array}$ & $\begin{array}{l}17(7.76 \%) \\
2(12.50 \%) \\
1(8.33 \%)\end{array}$ & $\begin{array}{l}\text { Ref } \\
1.69 \\
1.61\end{array}$ & $\begin{array}{l}(0.39- \\
7.37) \\
(0.21- \\
12.35)\end{array}$ & $\begin{array}{l}0.49 \\
0.65\end{array}$ \\
\hline
\end{tabular}

Abbreviations: SD, standard deviation; $\mathrm{Cl}$, confidence interval, eGFR, estimated glomerular filtration rate, CKD, chronic kidney disease 


\begin{tabular}{|c|c|c|c|c|c|}
\hline Demographics & $\begin{array}{l}\text { Mean } \pm \text { SD / } \\
\text { Numbers } \\
\text { (\% in column) } \\
n=247\end{array}$ & $\begin{array}{l}\text { Number of } \\
\text { Macroalbuminuria } \\
\text { (\% in row) } \\
n=20\end{array}$ & $\begin{array}{l}\text { Hazard } \\
\text { Ratio }\end{array}$ & $(95 \% \mathrm{Cl})$ & $\begin{array}{l}\mathrm{p}- \\
\text { value }\end{array}$ \\
\hline $\begin{array}{l}\text { Blood pressure (mmHg) } \\
\text { Systolic blood pressure } \\
\text { Diastolic blood pressure }\end{array}$ & $\begin{array}{l}133.91 \pm \\
16.20 \\
77.57 \pm 10.85\end{array}$ & $\begin{array}{l}134.80 \pm 15.77 \\
76.45 \pm 11.06\end{array}$ & $\begin{array}{l}1.01 \\
0.99\end{array}$ & $\begin{array}{l}(0.98- \\
1.04) \\
(0.96- \\
1.04)\end{array}$ & $\begin{array}{l}0.40 \\
0.72\end{array}$ \\
\hline HbA1c (\%) & $7.58 \pm 1.95$ & $7.84 \pm 1.80$ & 1.15 & $\begin{array}{l}(0.92- \\
1.44)\end{array}$ & 0.23 \\
\hline $\begin{array}{l}\text { Lipid profiles }(\mathrm{mg} / \mathrm{dL}) \\
\text { Total cholesterol } \\
\text { Triglyceride } \\
\text { High-density lipoprotein } \\
\text { Low-density lipoprotein }\end{array}$ & $\begin{array}{l}171.91 \pm \\
35.97 \\
163.69 \pm \\
134.50 \\
44.00 \pm 14.31 \\
106.98 \pm \\
30.84\end{array}$ & $\begin{array}{l}168.35 \pm 32.32 \\
221.95 \pm 187.65 \\
44.40 \pm 20.28 \\
100.50 \pm 29.59\end{array}$ & $\begin{array}{l}1.00 \\
1.002 \\
1.01 \\
0.997\end{array}$ & $\begin{array}{l}(0.99- \\
1.01) \\
(1.000- \\
1.004) \\
(0.98- \\
1.05) \\
(0.98- \\
1.01)\end{array}$ & $\begin{array}{l}0.98 \\
0.08 \\
0.45 \\
0.68\end{array}$ \\
\hline Baseline albuminuria & $40.06 \pm 59.66$ & $127.28 \pm 99.51$ & 1.01 & $\begin{array}{l}(1.01- \\
1.02)\end{array}$ & $\begin{array}{l}<.001 \\
0.001\end{array}$ \\
\hline Creatinine & $1.01 \pm 0.29$ & $1.19 \pm 0.29$ & 5.65 & $\begin{array}{l}(2.23- \\
14.33)\end{array}$ & $\begin{array}{l}<.001 \\
0.001\end{array}$ \\
\hline eGFR & $75.50 \pm 2.98$ & $64.30 \pm 21.04$ & 0.96 & $\begin{array}{l}(0.94- \\
0.99)\end{array}$ & $\begin{array}{l}< \\
0.001\end{array}$ \\
\hline \multicolumn{6}{|l|}{ CKD stage } \\
\hline 1 & $59(23.89 \%)$ & $1(5 \%)$ & Ref & & \\
\hline 2 & $128(51.82 \%)$ & $8(40 \%)$ & 3.53 & $\begin{array}{l}(0.44- \\
28.23)\end{array}$ & 0.24 \\
\hline $3 a$ & $48(19.43 \%)$ & $9(45 \%)$ & 12.51 & $\begin{array}{l}(1.58- \\
98.86)\end{array}$ & 0.02 \\
\hline $3 b$ & $10(4.05 \%)$ & $1(5 \%)$ & 10.91 & $\begin{array}{l}(0.67- \\
176.57)\end{array}$ & 0.09 \\
\hline 4 & $2(0.81 \%)$ & $1(5 \%)$ & 50.19 & $\begin{array}{l}(3.03- \\
832.39)\end{array}$ & 0.01 \\
\hline
\end{tabular}

A multivariate Cox proportional hazard model was used to investigate the factors associated with incident macroalbuminuria (Table 2). After adjusting for age, sex, body mass index, cigarette smoking, drinking habit, systolic blood pressure, $\mathrm{HbA} 1 \mathrm{c}$ levels, and lipid profiles, serum uric acid was significantly associated with increased risks of incident macroalbuminuria (AHR, 2.39, 95\% Cl 1.53-3.75, p<0.001). 
Other factors significantly associated with the development of macroalbuminuria were triglyceride levels (AHR, 1.01, 95\% Cl 1.00-1.01, p = 0.03), high-density lipoprotein levels (AHR, 1.07, 95\% Cl 1.01-1.13, p = 0.02), and $\mathrm{HbA} 1 \mathrm{c}(\mathrm{AHR}, 1.43,95 \% \mathrm{Cl} 1.10-1.86, \mathrm{p}=0.01)$. Increased total cholesterol level was significantly associated with a decreased risk of incident macroalbuminuria (AHR, $0.97,95 \% \mathrm{Cl} 0.94-1.00$, $p=0.047)$.

Table 2

Multivariable Cox regression analysis of the incidence of macroalbuminuria

\begin{tabular}{|c|c|c|c|}
\hline Demographics & Adjusted Hazard Ratio & $(95 \% \mathrm{Cl})$ & p-value \\
\hline Uric acid (mg/dL) & 2.39 & $(1.53-3.75)$ & $<0.001$ \\
\hline Age in years & 1.00 & $(0.94-1.06)$ & 0.95 \\
\hline $\begin{array}{l}\text { Gender } \\
\text { Female } \\
\text { Male }\end{array}$ & $\begin{array}{l}\text { Ref } \\
0.83\end{array}$ & $(0.19-3.65)$ & 0.80 \\
\hline $\begin{array}{l}\text { Smoking status } \\
\text { Never } \\
\text { Current } \\
\text { Former }\end{array}$ & $\begin{array}{l}\text { Ref } \\
1.53 \\
1.38\end{array}$ & $\begin{array}{l}(0.36-6.58) \\
(0.12-16.57)\end{array}$ & $\begin{array}{l}0.57 \\
0.80\end{array}$ \\
\hline $\begin{array}{l}\text { Drinking } \\
\text { Never } \\
\text { Current } \\
\text { Former }\end{array}$ & $\begin{array}{l}\text { Ref } \\
1.23 \\
1.01\end{array}$ & $\begin{array}{l}(0.21-6.89) \\
(0.08-13.17)\end{array}$ & $\begin{array}{l}0.83 \\
0.99\end{array}$ \\
\hline $\begin{array}{l}\text { Body mass index }\left(\mathrm{kg} / \mathrm{m}^{2}\right) \\
<24 \\
24 \leq \mathrm{BMI}<27 \\
\geq 27\end{array}$ & $\begin{array}{l}\text { Ref } \\
0.47 \\
0.31\end{array}$ & $\begin{array}{l}(0.11-2.01) \\
(0.07-1.36)\end{array}$ & $\begin{array}{l}0.31 \\
0.12\end{array}$ \\
\hline Systolic blood pressure $(\mathrm{mmHg})$ & 1.01 & $(0.98-1.05)$ & 0.56 \\
\hline HbA1c (\%) & 1.43 & $(1.10-1.86)$ & 0.01 \\
\hline Total cholesterol (mg/dL) & 0.97 & $(0.94-1.00)$ & 0.047 \\
\hline Triglyceride (mg/dL) & 1.01 & $(1.00-1.01)$ & 0.03 \\
\hline High-density lipoprotein (mg/dL) & 1.07 & $(1.01-1.13)$ & 0.02 \\
\hline Low-density lipoprotein (mg/dL) & 1.03 & $(1.00-1.06)$ & 0.11 \\
\hline
\end{tabular}

Figure 1 shows the ROC curve with the sensitivity and specificity of the equation to detect the incidence of macroalbuminuria. The uric acid cutoff point was $6.9 \mathrm{mg} / \mathrm{dL}$ (area under the curve, AUC 0.708, sensitivity $60.0 \%$, and specificity $84.58 \%$ ) for the incidence of macroalbuminuria.

\section{Discussion}


The current study revealed that an elevated serum uric acid level is associated with an increased risk of incident macroalbuminuria in people with type 2 diabetes. Previous research in animal models has suggested potential biological mechanisms for how hyperuricemia causes chronic renal dysfunction. Uric acid may impair nitric oxide production to induce endothelial cell dysfunction [10]. Moreover, hyperuricemia has been shown to trigger the renin-angiotensin system and damage vascular smooth muscle cells [6-8], leading ot the development of renal arteriolopathy, arterial hypertension, and then microvascular injury $[5,9,19]$. Another probable mechanism is the elevation of serum uric acid inducing inflammatory cytokine production, including tumor necrosis factor-a, C-reactive protein, interleukin-1 $\beta$, and interleukin-6 [20].

Previous studies in different settings with various study designs have reported similar findings in individuals with type 2 diabetes [13-16]. In both cross-sectional and cohort researches, uric acid was reported to be related to diabetic nephropathy. In cross-sectional studies, serum uric level was related with microalbuminuria in Korean, Taiwanese, and Chinese people with type 2 diabetes [13, 21, 22]. A cohort study in Japan reported that diabetic patients with increased serum uric acid levels had increased risk of deterioration of diabetic nephropathy defined as shifting from microalbuminuria to albuminuria. However, this study also showed that uric acid was not associated with the risk of shifting from normoalbuminuria to microalbuminuria or macroalbuminuria [23]. This may be because the follow-up period of the study was only 2 years, which was too short for the occurrence of diabetic nephropathy. A cohort study with a 4-year follow-up duration in Italy revealed that serum uric acid was significantly associated with risk of incident macroalbuminuria only if the estimated glomerular filtration rate $<60 \mathrm{ml} / \mathrm{min}$ per $1.73 \mathrm{~m}^{2}$ [16]. Another cohort study with a follow-up duration of 5 years reported that uric acid was related to risk of incident diabetic nephropathy defined as an estimated glomerular filtration rate less than $60 \mathrm{ml} / \mathrm{min}$ per $1.73 \mathrm{~m}^{2}$ or an albumin-creatinine ratio greater $30 \mathrm{mg} / \mathrm{mmol}$ [15]. However, most of the study subjects were white, and race has some impact on the risk of kidney function progression [24].

As far as we know, few researches have reported the uric acid cutoff for an increased risk of impaired renal function. A cohort study in Italy reported that hyperuricemia is associated with incident diabetic nephropathy, and the definition of hyperuricemia was a serum uric acid level greater $7.0 \mathrm{mg} / \mathrm{dL}$ in men and greater than $6.6 \mathrm{mg} / \mathrm{dL}$ in women [15]. These cutoff values were those generally used to define hyperuricemia in their medical laboratory. The current study showed that the uric acid level cutoff for an increased risk of incident diabetic nephropathy was $6.9 \mathrm{mg} / \mathrm{dL}$, which was calculated by the area under the ROC curve.

Previous studies had also reported that reducing the serum uric acid concentration can reduce kidney damage and recover renal function in diabetic mice, which suggested that the nephropathy caused by a high serum uric acid concentration might be reversible [25]. Momeni et al. thus conducted a doubleblinded randomized controlled trial recruiting people with diabetic nephropathy, reporting that the serum uric acid concentration decreased after allopurinol management for 4 months, and the 24-hour urine protein excretion also decreased [26]. Another single-blind, randomized, controlled trial showed that allopurinol therapy for 2 years enhanced the estimated glomerular filtration rate and decreased 
cardiovascular risks $[27,28]$. However, to date, despite some preliminary pilot studies of randomized clinical trials of allopurinol [26-28], there is still limited evidence regarding pharmacological intervention to reduce serum uric acid levels and thus prevent the deterioration of renal function.

One strength of the current study is the highly detailed demographic information of the participants collected by well-trained interviewers, including socioeconomic status, smoking habits, and alcohol consumption, which were proven to be potential confounders. Laboratory tests, including fasting blood glucose, $\mathrm{HbA} 1 \mathrm{c}$, uric acid, creatinine, lipid profiles, and urine albumin-creatinine ratio were achieved by standardized processes at the hospital with high accuracy. Moreover, there were few missing values in our dataset. The study was a cohort survey with longitudinal follow-up for 4.5 years, resulting in adequate relationships for causal inference. However, there are also some limitations to be borne in mind. The study was performed at the outpatient department of the Puli Branch of Taichung Veterans Hospital, which is a local hospital. Individuals with disabilities, those who were bedridden, and those who were unable to answer the questionnaire were excluded from the study, which might limit its generalizability. Moreover, recall bias on the self-reported questionnaire might be another concern. Only uric acid levels at baseline were collected, and the change over time was not measured; thus, the influence of uric acid on the incidence of diabetic nephropathy over time was not estimated. Medications, including anti-diabetic drugs, hypertensive drugs, and urate-lowering drugs were not included in the study because we believe that the effect of medication could be estimated by the laboratory data, including HbA1c, uric level, lipid profiles, and blood pressure measurements.

\section{Conclusions}

Integrated treatment policies for diabetic nephropathy consist of intensive glycemic control, appropriate blood pressure management, smoking cessation, and regular screening of the urine albumin-creatinine ratio. Our study revealed an association between increased uric acid levels and the development of macroalbuminuria in people with type 2 diabetes. Further research with an observational or interventional study design with an adequate sample size and better generalizability will enhance the understanding of causal relation of uric acid in renal function deterioration in people with diabetes.

\section{Abbreviations}

AHR:Adjusted hazard ratios; Cl:confidence intervals; AUC:area under curve; ROC:receiver operator characteristic

\section{Declarations}

\section{Ethics approval and consent to participate}

This research was permitted by the ethics committee of the Taichung Veterans General Hospital (SE13300). 
Consent for publication

Not applicable.

Availability of data and materials

Data sets used and analyzed in current research may be obtained from the corresponding author as reasonably required.

\section{Competing interests}

All authors declare that they have no conflict of interest.

\section{Funding}

None

\section{Authors' contributions}

YFY, YYC, and YKL contributed considerably to study design and conception. LJC and PWK explored and explained the data and composed the initial version of the manuscript. YFY, YJL, and $\mathrm{KCH}$ obtained the data and conceived of the study project, contributed in the statistics analysis. All authors seriously edited the document and gave final approval.

\section{Acknowledgments}

None

\section{References}

1. Ritz E, Rychlik I, Locatelli F, Halimi S: End-stage renal failure in type 2 diabetes: A medical catastrophe of worldwide dimensions. Am J Kidney Dis 1999, 34(5):795-808.

2. Glassock RJ: Is the presence of microalbuminuria a relevant marker of kidney disease? Curr Hypertens Rep 2010, 12(5):364-368.

3. Halbesma N, Kuiken DS, Brantsma AH, Bakker SJ, Wetzels JF, De Zeeuw D, De Jong PE, Gansevoort RT: Macroalbuminuria is a better risk marker than low estimated GFR to identify individuals at risk for accelerated GFR loss in population screening. J Am Soc Nephrol 2006, 17(9):2582-2590.

4. Ravid M, Brosh D, Ravid-Safran D, Levy Z, Rachmani R: Main risk factors for nephropathy in type 2 diabetes mellitus are plasma cholesterol levels, mean blood pressure, and hyperglycemia. Arch Intern Med 1998, 158(9):998-1004.

5. Mene P, Punzo G: Uric acid: bystander or culprit in hypertension and progressive renal disease? J Hypertens 2008, 26(11):2085-2092. 
6. Oh J, Won HY, Kang SM: Uric acid and cardiovascular risk. N Engl J Med 2009, 360(5):539-540; author reply 540-531.

7. Sanchez-Lozada LG, Tapia E, Santamaria J, Avila-Casado C, Soto V, Nepomuceno T, Rodriguez-Iturbe $\mathrm{B}$, Johnson RJ, Herrera-Acosta J: Mild hyperuricemia induces vasoconstriction and maintains glomerular hypertension in normal and remnant kidney rats. Kidney Int 2005, 67(1):237-247.

8. Ryu ES, Kim MJ, Shin HS, Jang YH, Choi HS, Jo I, Johnson RJ, Kang DH: Uric acid-induced phenotypic transition of renal tubular cells as a novel mechanism of chronic kidney disease. $A m \mathrm{~J}$ Physiol Renal Physiol 2013, 304(5):F471-480.

9. Mazzali M, Hughes J, Kim YG, Jefferson JA, Kang DH, Gordon KL, Lan HY, Kivlighn S, Johnson RJ: Elevated uric acid increases blood pressure in the rat by a novel crystal-independent mechanism. Hypertension 2001, 38(5):1101-1106.

10. Khosla UM, Zharikov S, Finch JL, Nakagawa T, Roncal C, Mu W, Krotova K, Block ER, Prabhakar S, Johnson RJ: Hyperuricemia induces endothelial dysfunction. Kidney Int 2005, 67(5):1739-1742.

11. Ryoo JH, Choi JM, Oh CM, Kim MG: The association between uric acid and chronic kidney disease in Korean men: a 4-year follow-up study. J Korean Med Sci 2013, 28(6):855-860.

12. Chang HY, Lee PH, Lei CC, Tung CW, Hsu YC, Huang TJ, Lu LC, Lin CL: Hyperuricemia is an independent risk factor for new onset micro-albuminuria in a middle-aged and elderly population: a prospective cohort study in taiwan. PLoS One 2013, 8(4):e61450.

13. Kim ES, Kwon HS, Ahn CW, Lim DJ, Shin JA, Lee SH, Cho JH, Yoon KH, Kang MI, Cha BY et al: Serum uric acid level is associated with metabolic syndrome and microalbuminuria in Korean patients with type 2 diabetes mellitus. J Diabetes Complications 2011, 25(5):309-313.

14. Fukui M, Tanaka M, Shiraishi E, Harusato I, Hosoda H, Asano M, Kadono M, Hasegawa G, Yoshikawa $\mathrm{T}$, Nakamura N: Serum uric acid is associated with microalbuminuria and subclinical atherosclerosis in men with type 2 diabetes mellitus. Metabolism 2008, 57(5):625-629.

15. Zoppini G, Targher G, Chonchol M, Ortalda V, Abaterusso C, Pichiri I, Negri C, Bonora E: Serum uric acid levels and incident chronic kidney disease in patients with type 2 diabetes and preserved kidney function. Diabetes Care 2012, 35(1):99-104.

16. De Cosmo S, Viazzi F, Pacilli A, Giorda C, Ceriello A, Gentile S, Russo G, Rossi MC, Nicolucci A, Guida $\mathrm{P}$ et al: Serum Uric Acid and Risk of CKD in Type 2 Diabetes. Clin J Am Soc Nephro/ 2015, 10(11):1921-1929.

17. Pan WH, Lee MS, Chuang SY, Lin YC, Fu ML: Obesity pandemic, correlated factors and guidelines to define, screen and manage obesity in Taiwan. Obes Rev 2008, 9 Suppl 1:22-31.

18. Toto RD: Microalbuminuria: definition, detection, and clinical significance. J Clin Hypertens (Greenwich) 2004, 6(11 Suppl 3):2-7.

19. Mazzali M, Kanellis J, Han L, Feng L, Xia YY, Chen Q, Kang DH, Gordon KL, Watanabe S, Nakagawa T et al: Hyperuricemia induces a primary renal arteriolopathy in rats by a blood pressure-independent mechanism. Am J Physiol Renal Physiol 2002, 282(6):F991-997. 
20. Lyngdoh T, Marques-Vidal P, Paccaud F, Preisig M, Waeber G, Bochud M, Vollenweider P: Elevated serum uric acid is associated with high circulating inflammatory cytokines in the population-based Colaus study. PLoS One 2011, 6(5):e19901.

21. Yan D, Tu Y, Jiang F, Wang J, Zhang R, Sun X, Wang T, Wang S, Bao Y, Hu C et al: Uric Acid is independently associated with diabetic kidney disease: a cross-sectional study in a Chinese population. PLoS One 2015, 10(6):e0129797.

22. Liang CC, Lin PC, Lee MY, Chen SC, Shin SJ, Hsiao PJ, Lin KD, Hsu WH: Association of Serum Uric Acid Concentration with Diabetic Retinopathy and Albuminuria in Taiwanese Patients with Type 2 Diabetes Mellitus. Int J Mol Sci 2016, 17(8).

23. Hayashino Y, Okamura S, Tsujii S, Ishii H: Association of serum uric acid levels with the risk of development or progression of albuminuria among Japanese patients with type 2 diabetes: a prospective cohort study [Diabetes Distress and Care Registry at Tenri (DDCRT 10)]. Acta Diabetol 2016, 53(4):599-607.

24. Bhalla V, Zhao B, Azar KM, Wang EJ, Choi S, Wong EC, Fortmann SP, Palaniappan LP: Racial/ethnic differences in the prevalence of proteinuric and nonproteinuric diabetic kidney disease. Diabetes Care 2013, 36(5):1215-1221.

25. Kosugi T, Nakayama T, Heinig M, Zhang L, Yuzawa Y, Sanchez-Lozada LG, Roncal C, Johnson RJ, Nakagawa T: Effect of lowering uric acid on renal disease in the type 2 diabetic $\mathrm{db} / \mathrm{db}$ mice. $A m \mathrm{~J}$ Physiol Renal Physiol 2009, 297(2):F481-488.

26. Momeni A, Shahidi S, Seirafian S, Taheri S, Kheiri S: Effect of allopurinol in decreasing proteinuria in type 2 diabetic patients. Iran J Kidney Dis 2010, 4(2):128-132.

27. Goicoechea M, Garcia de Vinuesa S, Verdalles U, Verde E, Macias N, Santos A, Perez de Jose A, Cedeno S, Linares T, Luno J: Allopurinol and progression of CKD and cardiovascular events: longterm follow-up of a randomized clinical trial. Am J Kidney Dis 2015, 65(4):543-549.

28. Goicoechea M, de Vinuesa SG, Verdalles U, Ruiz-Caro C, Ampuero J, Rincon A, Arroyo D, Luno J: Effect of allopurinol in chronic kidney disease progression and cardiovascular risk. Clin J Am SoC Nephrol 2010, 5(8):1388-1393.

\section{Figures}




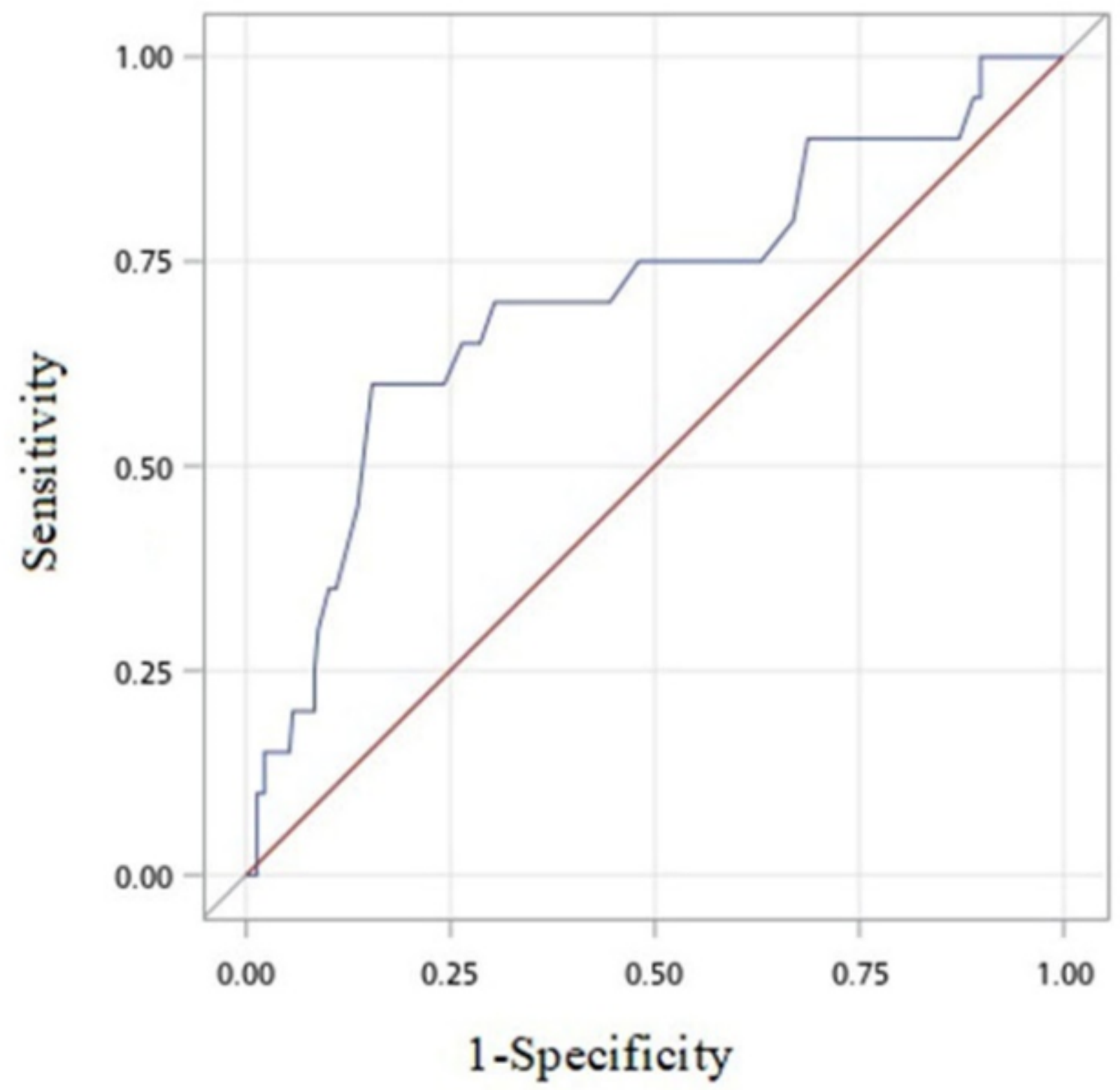

Figure 1

Receiver operating characteristic curve showing the sensitivity and specificity of the equation to detect the incidence of macroalbuminuria 